\title{
Metabolic responses to low doses of cyanocobalamin in patients with megaloblastic anaemia
}

\author{
BY J. F. ADAMS, R. HUME, ELIZABETH H. KENNEDY, T. G. PIRRIE \\ AND J. W. WHITELAW \\ Southern General Hospital, Glasgow
}

AND A. M. WHITE

CIBA Research Laboratories, Horsham, Sussex

(Received I9 October 1967-Accepted 21 March 1968)

\begin{abstract}
I. The metabolic responses to daily treatment with I $\mu \mathrm{g}$ cyanocobalamin were studied in sixteen patients with megaloblastic anaemia due to cobalamin deficiency.

2. The fall in serum iron was sluggish in most patients. The pattern of reticulocyte responses varied widely, the most common being a plateau with suboptimal maximal value.

3. Urinary propionic acid excretion before treatment was normal in two out of six patients. A transient rise during treatment was observed in two patients, possibly owing to demands on coenzyme stores. The fall in urinary propionic acid excretion during treatment was slow.

4. Serum vitamin $B_{12}$ levels rose during treatment. In two patients an abrupt rise was found, possibly owing to release of stored cobalamin into the circulation.
\end{abstract}

The use of small parenteral doses of cyanocobalamin or pteroylmonoglutamic acid in the treatment of megaloblastic anaemias has been advocated as a diagnostic as well as a therapeutic procedure (Marshall \& Jandl, I960). The rationale of such therapeutic trials is that in megaloblastic anaemias treatment with conventional doses of either cyanocobalamin or pteroylmonoglutamic acid may result in a non-specific haematological response: that is, cyanocobalamin may induce a response when the deficiency is solely of folic acid and, conversely, pteroylmonoglutamic acid may induce a response when the deficiency is solely of cobalamins. When small doses approximating to the daily requirement are given parenterally, thus eliminating problems of absorption, non-specific responses do not occur and the response to treatment is then of diagnostic as well as therapeutic value. Previous work on therapeutic trials has been directed in the main to establishing a suitable dose of pteroylmonoglutamic acid (Marshall \& Jandl, 1960; Hansen \& Weinfeld, 1962) and the responses to treatment with small doses of cyanocobalamin have not been studied in detail. We have studied the responses in a group of cobalamin-deficient patients treated with I $\mu \mathrm{g}$ cyanocobalamin intramuscularly each day and report our findings in this paper.

\section{EX PERIMENTAL}

Sixteen patients were studied. All were anaemic and megaloblastic erythropoiesis was found on marrow biopsy. The final diagnosis in patients nos. $\mathbf{I}-\mathbf{I} 2$ was Addisonian pernicious anaemia and in nos. $I 3$ and 14 megaloblastic anaemia following partial gastrectomy. The diagnosis of intestinal malabsorption in no. 16 was based on the findings given in Table $\mathrm{I}$, on evidence of malabsorption of oral glucose and on the 
finding of mucosal atrophy on peroral jejunal biopsy. The diagnosis in no. I 5 was not established and it was not possible to carry out further investigations.

After an observation period of $2-5$ days, during which the initial diagnostic investigations were made, daily treatment with $\mathrm{I} \mu \mathrm{g}$ cyanocobalamin given intramuscularly was begun, the first day of treatment being designated day 0 . Treatment was continued for at least 14 days and the injection was given at the same time each day. During the period of treatment blood samples were obtained immediately before injection. The patients were nursed in a general ward and offered a ward diet modified to exclude liver and to contain little milk or egg. The daily diet was calculated to contain $70 \mathrm{~g}$ protein, $97 \mathrm{~g}$ fat, $0.6 \mu \mathrm{g}$ cobalamins, $5 \mu \mathrm{g}$ folic acids and to have an energy value of $2000 \mathrm{kcal}$. The technical methods employed were as follows: haemoglobin, packed red cell volume and reticulocyte count (Dacie \& Lewis, 1963); augmented histamine gastric secretion (Kay, 1953), the $\mathrm{pH}$ of the aspirate being measured electrometrically; serum iron (Ramsay, 1957); serum folate (Waters \& Mollin, I963); urine xylose in the $5 \mathrm{~h}$ after an oral dose of $5 \mathrm{~g}$ (Roe \& Rice, I948); urine formiminoglutamic acid (Figlu) in the 4-9 h after $15 \mathrm{~g}$ histidine orally (Kohn, Mollin \& Rosenbach, I96I); gastric parietal cell antibodies (Adams, Glen, Kennedy, Mackenzie, Morrow, Anderson, Gray \& Middleton, 1964); faecal fat in a 3-day collection by the method of Cammidge (Varley, I958); absorption of I $\mu \mathrm{g}$ radioactive cyanocobalamin by mouth (Schilling, I953); in vitro intrinsic factor assay (Gottlieb, Lau, Wasserman \& Herbert, 1965 ) and propionic acid in a $24 \mathrm{~h}$ collection of urine (White, I965). At the conclusion of each trial all samples from each patient were assayed together in at least two assays for serum vitamin $B_{12}$ (Hutner, Bach \& Ross, 1956).

\section{RESULTS}

The results of the pretreatment and other diagnostic investigations are shown in Table I.

The pretreatment serum iron values ranged from 80 to $260 \mu \mathrm{g} / \mathrm{100} \mathrm{ml}$. In only one of twelve patients had the value fallen to $60 \mu \mathrm{g} / 100 \mathrm{ml}$ on day 2 , this value occurring in the other patients between days 3 and $1_{5}$ (Table 2).

The reticulocyte count rose to at least $9 \%$ in all patients during the treatment period but the maximum value and pattern of response varied greatly. Plateau responses were more common than peak responses; when the latter did occur the maximum value occurred between days 5 and 9 (Table 3 ).

Pretreatment urinary propionic acid values were high in four patients and within normal limits in two. The effect of treatment was observed in five of these patients, including the two with normal pretreatment values, and in one with a high value on day I: three patients showed a fall, two including one with normal pretreatment value, a rise followed by a fall, and one, with a normal pretreatment value, did not change (Table 4).

Urinary Figlu estimations during the period of treatment were carried out in eight patients, all of whom had had an excessive amount before, or on day I or 2 of treatment. In three the values fell and in five they were unaltered by treatment. 
Vol. 22

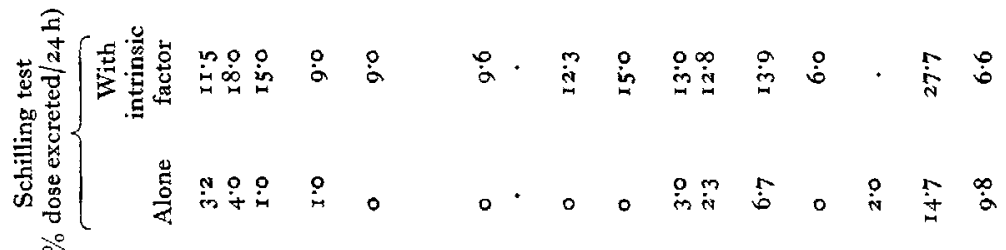
i̊

家嗙

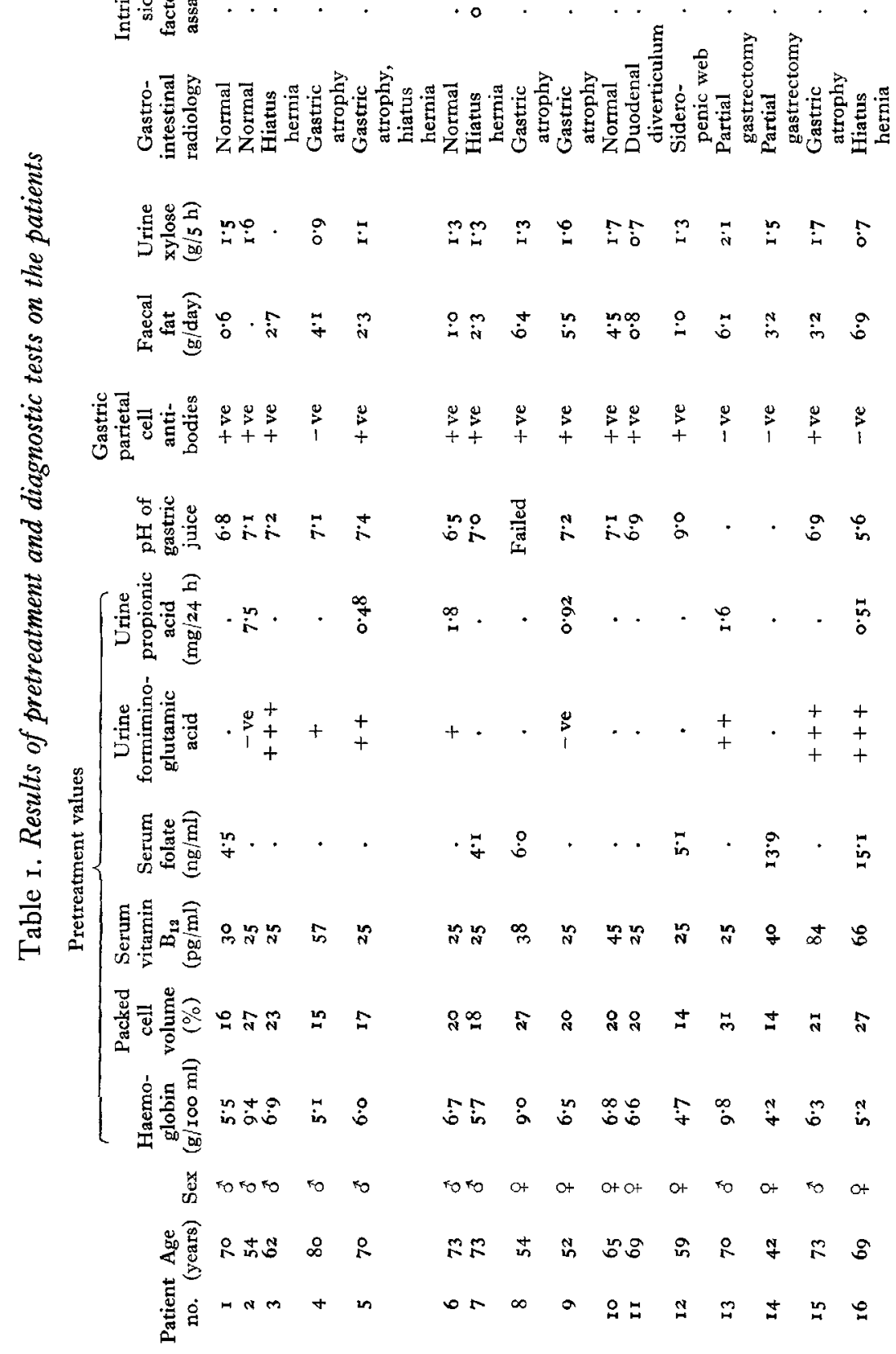


Pretreatment serum vitamin $B_{12}$ levels were less than $85 \mathrm{pg} / \mathrm{ml}$ in all patients. During treatment a rise always occurred, but the pattern varied from an abrupt rise to normality on day I in two patients to a slow rise to values in the region of $140 \mathrm{pg} / \mathrm{ml}$ by the end of the treatment period (Table 5).

Table 2. Serum iron values of the patients before and during treatment with I $\mu$ g cyanocobalamin/day given intramuscularly

Pre-

\begin{tabular}{|c|c|c|c|c|c|c|c|c|c|c|c|c|c|c|c|c|}
\hline \multicolumn{2}{|c|}{ Patient treatment } & \\
\hline & value & $\mathbf{I}$ & 2 & 3 & 4 & 5 & 6 & 7 & 8 & 9 & 10 & I I & 12 & I3 & 14 & I5 \\
\hline $\mathbf{I}$ & 220 & . & 140 & 95 & $\cdot$ & 42 & $\cdot$ & 50 & $\cdot$ & 50 & . & $\cdot$ & . & . & 25 & . \\
\hline 2 & 180 & . & 100 & . & 50 & $\cdot$ & 25 & . & 45 & & . & $5 \mathrm{I}$ & . & . & 70 & $\therefore$ \\
\hline 3 & 200 & . & - & 140 & 125 & . & 85 & . & - & 80 & . & . & . & . & . & 60 \\
\hline 4 & 125 & - & 100 & · & $\cdot$ & 40 & $\cdot$ & . & . & 20 & $\therefore$ & . & . & . & . & . \\
\hline 5 & 145 & I 45 & I60 & . & 140 & . & . & 35 & . & . & 85 & . & . & . & 50 & . \\
\hline 6 & 170 & 175 & . & . & 125 & . & . & 80 & . & . & . & . & . & . & $4^{\circ}$ & . \\
\hline 7 & 105 & 105 & 95 & 62 & & . & . & . & 30 & . & . & . & . & . & . & . \\
\hline 8 & 225 & 155 & I 35 & 100 & 60 & . & 40 & . & . & . & 20 & . & . & 40 & . & . \\
\hline 9 & I75 & . & I IO & . & I IO & . & 70 & . & . & . & 55 & . & . & . & 90 & . \\
\hline ro & I 30 & 88 & 90 & . & . & . & . & . & . & . & . & 50 & . & 35 & . & . \\
\hline I I & 130 & . & 95 & . & . & . & . & . & . & . & . & . & . & . & . & . \\
\hline 12 & 135 & 150 & 87 & 50 & . & . & . & . & 45 & . & . & . & . & . & . & . \\
\hline I3 & I 75 & I5 & I 5 & . & 20 & . & . & . & . & 40 & . & . & . & . & . & . \\
\hline I 4 & 260 & 105 & . & 30 & 50 & . & 50 & . & . & . & 30 & . & 35 & . & . & . \\
\hline I 5 & 80 & . & . & 95 & 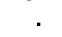 & 20 & . & . & 45 & . & 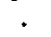 & . &. & . & . & $3^{x}$ \\
\hline 16 & I35 & . & 170 & . & I 23 & . & . & 55 & . & . & . & . & . & . & . & . \\
\hline
\end{tabular}

Table 3. Reticulocyte counts of patients during treatment with I $\mu$ g cyanocobalamin/day given intramuscularly

\begin{tabular}{|c|c|c|c|c|c|c|c|c|c|c|c|c|c|c|c|c|c|c|c|}
\hline \multirow{2}{*}{$\begin{array}{c}\text { Patient } \\
\text { no. }\end{array}$} & \multicolumn{19}{|c|}{ Count $(\%)$ on day of treatment: } \\
\hline & $\circ$ & I & 2 & 3 & 4 & 5 & 6 & 7 & 8 & 9 & IO & II & 12 & 13 & 14 & I 5 & 16 & I7 & I 8 \\
\hline I & 2 & $\mathbf{r}$ & 3 & 4 & 6 & 12 & 17 & I 5 & 12 & 18 & 10 & 8 & . & $\cdot$ & 5 & 3 & 4 & 4 & - \\
\hline 2 & $\cdot$ & I & $\mathbf{I}$ & I & 8 & $\cdot$ & 17 & 18 & 20 & 16 & I I & 5 & 7 & $\cdot$ & 7 & 4 & 5 & 2 & - \\
\hline 3 & $\cdot$ & $\mathbf{I}$ & 2 & · & 2 & 3 & 4 & 4 & $\dot{0}$ & $\dot{x}$ & $\cdot$ & 9 & 6 & 5 & 7 & 7 & 4 & 4 & - \\
\hline 4 & . & 2 & . & 2 & 4 & 9 & 13 & I I & 8 & 6 & 5 & 5 & 6 & . & . & . & . & . & . \\
\hline 5 & 2 & 2 & 2 & 2 & 2 & $\cdot$ & IO & I4 & I9 & 35 & $3 I$ & I4 & • & 7 & 8 & . & . & . & . \\
\hline 6 & I & . & $\mathbf{I}$ & 2 & 2 & 2 & 5 & 9 & I4 & 14 & . & II & IO & 7 & $\cdot$ & . & . & . & . \\
\hline 7 & 4 & 3 & 3 & 4 & 4 & 9 & 4 & 4 & I I & 5 & 4 & 5 & 3 & 3 & 4 & 4 & 3 & 2 & . \\
\hline 8 & . & 2 & 2 & 2 & 3 & . & 6 & 6 & 6 & 5 & 19 & I 2 & . & . & 7 & 6 & 3 & 4 & I \\
\hline 9 & 3 & 2 & 2 & 2 & 2 & 3 & 8 & 13 & . & $\mathrm{I}_{4}$ & 14 & 10 & I3 & 8 & 7 & . & 5 & 5 & 5 \\
\hline Io & . & . & 2 & 2 & 8 & 8 & ro & • & IO & IO & 9 & 5 & 3 & 3 & 3 & 4 & 3 & 7 & 7 \\
\hline I I & 2 & 3 & . & 5 & . & 3 & 7 & 9 & 8 & IO & . & . & II & 9 & IO & 7 & 6 & 5 & . \\
\hline I 2 & 2 & 2 & 2 & 2 & 4 & 35 & I6 & 17 & I 5 & 8 & 8 & 9 & 6 & 8 & 9 & 9 & 6 & . & 3 \\
\hline I3 & I & I & 2 & 2 & 3 & 6 & 9 & 2 & 2 & 2 & 2 & . & . & . & . & . & . & . & . \\
\hline 14 & 2 & 2 & 3 & 5 & 23 & 33 & 20 & I I & & . & I 3 & 15 & 12 & 5 & . & • & . & . & . \\
\hline I 5 & I & I & I & I & . & 8 & I 4 & I9 & I8 & IO & 8 & • & 6 & . & . & . & . & . & . \\
\hline 16 & . & . & 4 & 4 & 4 & 3 & 4 & . & 10 & 14 & I3 & . & 25 & . & 7 & 6 & . & . & \\
\hline
\end{tabular}

\section{DISCUSSION}

In clinical practice the earliest objective signs of a haematological response which follows the administration of cyanocobalamin to an anaemic cobalamin-deficient subject are a fall in serum iron and a rise in reticulocyte count. With conventional 
Table 4. Urinary propionic acid values of the patients before and during treatment with I $\mu$ g cyanocobalamin/day given intramuscularly

\begin{tabular}{|c|c|c|c|c|c|c|c|}
\hline \multirow{2}{*}{$\begin{array}{c}\text { Patient } \\
\text { no. }\end{array}$} & \multirow{2}{*}{$\begin{array}{l}\text { Pre- } \\
\text { treatment } \\
\text { value }\end{array}$} & \multicolumn{6}{|c|}{ Value $(\mathrm{mg} / 24 \mathrm{~h})$ on day of treatment: } \\
\hline & & $\mathbf{I}$ & 7 & 8 & I I & 14 & I6 \\
\hline 2 & $7 \cdot 4$ & . & I I $\cdot 9$ & . & . & $4 \cdot 3$ & . \\
\hline 3 & $\cdot$ & 14.7 & . & . & $3 \cdot 2$ & - & $I \cdot 2$ \\
\hline 5 & 0.48 & . & . & $4 \cdot 2$ & . & 0.82 & . \\
\hline 6 & I 8 & . & 0.76 & . & . & . & . \\
\hline 9 & 0.92 & . & . & 0.43 & . & 0.41 & . \\
\hline I3 & $\mathbf{I} \cdot 6$ & . & . & $\cdot$ & . & $\cdot$ & . \\
\hline 16 & $0.5 I$ & . & . & 0.43 & . & . & 0.36 \\
\hline
\end{tabular}

Table 5. Serum vitamin $\mathrm{B}_{12}$ levels of the patients before and during treatment with I $\mu \mathrm{g}$ cyanocobalamin/day given intramuscularly

\begin{tabular}{|c|c|c|c|c|c|c|c|c|c|c|c|c|c|c|c|c|}
\hline \multirow{2}{*}{$\begin{array}{c}\text { Patient } \\
\text { no. }\end{array}$} & \multirow{2}{*}{$\begin{array}{l}\text { Pretreatment } \\
\text { value }\end{array}$} & \multicolumn{15}{|c|}{ Value $(\mu \mathrm{g} / \mathrm{ml})$ on day of treatment: } \\
\hline & & $\mathbf{I}$ & 2 & 3 & 4 & 5 & 6 & 7 & 8 & 9 & IO & I I & 12 & I3 & 14 & I5 \\
\hline I & 30 & . & 97 & I I 2 & . & 125 & . & I 55 & . & . & 140 & . & . & 144 & . & . \\
\hline 2 & $<25$ & . & . & 53 & . & 99 & . & . & I 29 & . & . & 139 & . & . & . & . \\
\hline 3 & $<25$ & . & . & . & . & . & 117 & . & $\cdot$ & . & . & - & $\cdot$ & . & . & 125 \\
\hline 4 & 57 & . & . & . & . & . & I 4 I & . & . & . & . & . & $22 \mathrm{I}$ & . & . & . \\
\hline 5 & $<25$ & . & . & 36 & . & . & 35 & . & . & $7^{8}$ & . & 79 & II 7 & . & . & . \\
\hline 6 & $<25$ & . & . & . & . & . & 324 & . & . & . & . & 342 & . & . & 231 & . \\
\hline 7 & $<25$ & 50 & 71 & I 47 & . & . & . & . & 123 & . & . & . & . & . & . & . \\
\hline 8 & $3^{8}$ & 65 & . & . & . & . & II 2 & . & . & . & 140 & . & . & . & . & . \\
\hline 9 & $<25$ & . & . & 25 & . & 74 & . & . & 266 & . & 278 & . & . & . & 313 & . \\
\hline IO & 45 & . & . & 233 & . & . & . & . & . & 223 & . & . & . & . & . & . \\
\hline I I & $<25$ & . & . & . & . & . & . & I 82 & . & . & . & . & . & 222 & . & . \\
\hline 12 & $<25$ & . & 25 & 53 & 62 & . & . & . & 86 & . & . & . & . & . & . & . \\
\hline 13 & $<25$ & 374 & . & . & 410 & . & . & . & . & 404 & . & 44 I & . & . & . & . \\
\hline 14 & 40 & 271 & 284 & . & 218 & . &. & . & - &. & 487 & . & $3^{67}$ & . & . & . \\
\hline I 5 & 84 & . & . & . & . & 253 & . & . & 270 & . & . & . & 326 & . & . & 311 \\
\hline I6 & 66 & . & $8 I$ & . & . & 98 & I 16 & . & . & 239 & . & . & 141 & . & 148 & . \\
\hline
\end{tabular}

therapeutic doses, $100-1000 \mu \mathrm{g}$, the serum iron falls to $50-60 \mu \mathrm{g} / \mathrm{I} 00 \mathrm{ml}$ within $48 \mathrm{~h}$ (Hawkins, 1955) and the reticulocyte count to a peak on days 5 to 7 (Ungley, 1949). By these standards the responses to I $\mu \mathrm{g}$ cyanocobalamin daily are usually delayed and less dramatic. No factors were found to account for the uncommon optimal responses, and the individual serum iron and reticulocyte responses were not related to age, sex, degree of anaemia, pretreatment serum vitamin $B_{12}$ level or, in the small number of cases with appropriate studies, to the pretreatment serum folate level or urine propionic acid value. The fact that the serum iron and reticulocyte responses to I $\mu$ g cyanocobalamin daily differ considerably from those following treatment with conventional doses is of considerable practical importance.

The choice of a $1 \mu \mathrm{g}$ dose was based on studies by Darby, Bridgforth, Le Brocuy, Clark, De Oliviera, Kevany, McGanity \& Perez (1958), who suggested that the daily requirement for cobalamins was in the region of $0.5^{-1} \mu \mathrm{g}$. More recent work by Heyssel, Bozian, Darby \& Bell (I966) and Boddy \& Adams (I968), both using whole body monitoring techniques, indicates that the requirement to maintain balance is 
related to the body stores of cobalamins and lies in the range $0.1-0.2 \%$ of body stores per day. The requirement of an anaemic, cobalamin-deficient subject is thus very small and it is of interest to note that haematological responses have been induced by as little as $0 . \mathrm{I} \mu \mathrm{g}$ cyanocobalamin daily (Sullivan \& Herbert, $\mathrm{I}_{96} 6_{5}$ ), the responses presumably resulting from administration of amounts greater than those required simply to maintain balance. The problem of the best dose of cyanocobalamin for therapeutic trials is difficult. In the majority of our patients the reticulocyte response was suboptimal, and as such responses may follow a variety of substances such as antibiotics, choline, serine and histidine it could be argued that a $\mathrm{r} \mu \mathrm{g}$ dose is too small and that a larger dose, which would induce optimal reticulocyte responses, is necessary to demonstrate specificity of response. On the other hand, it is extremely unlikely that the responses in our patients were non-specific, and from this it follows that a specific response is not necessarily manifested by optimal reticulocytosis. Ungley (1949) considered that the reticulocyte dose response curve was sigmoid, rising gradually, then steeply and flattening out at a supramaximal level. In this instance adjustment of dosage to ensure optimal reticulocyte responses is simply a matter of clinical convenience. There is some evidence from therapeutic trials by Hansen \& Weinfeld ( 1962 ) that a daily dose of $3 \mu \mathrm{g}$ cyanocobalamin will induce optimal reticulocyte responses and, on reflection, we feel that such a dose is more suitable for clinical purposes than I $\mu \mathrm{g}$ daily.

The results of the serial urinary propionic acid and serum vitamin $B_{12}$ estimations have intrinsic interest. In cobalamin deficiency the isomerization of methylmalonyl coenzyme $A$ to succinyl coenzyme $A$ is reduced and the amount of methylmalonic acid in urine is increased and provides a measure of the defect (Cox \& White, 1962; Vivacqua, Myerson, Prescott \& Rabinowitz, I966; Gompertz, Jones \& Knowles, 1967). The preceding reaction, carboxylation of propionyl coenzyme A to methylmalonyl coenzyme $A$, although not dependent on the cobalamin coenzymes, is also affected (White, I965) and the amount of propionic acid in urine is increased. The three points of interest in the results in this series are the normal pretreatment values obtained in two patients, the rise in amount excreted during treatment in two patients and the responses to treatment in the others. The two normal pretreatment values may be related to the fact that the measurement is one of a metabolic consequence one stage removed from the actual defect, thus leading to a lack of precision in delineating 'normal' from 'deficient' values, a problem which is discussed by Cox, Robertson-Smith, Small \& White (I968). The rise in amount of propionic acid excreted by patients 2 and 5 during treatment may be explained by the demands made upon the cobalamin coenzyme stores by the reticulocyte response with the result that the methylmalonyl coenzyme A mutase is further 'stripped of' its coenzyme: this explanation is supported by the fact that the reticulocyte responses in the two patients were the greatest in the group in whom urinary propionic acid was estimated, being $20 \%$ on day 8 in no. 2 and $35 \%$ on day 7 in no. 5 . The fall in urinary propionic acid in this series was slow in contrast to the rapid fall observed following treatment with conventional therapeutic doses of cyanocobalamin (Cox et al. I968).

The serial serum vitamin $B_{12}$ values rose during treatment in every instance but there was no consistent pattern and no correlation could be found between the 
patterns and other responses. Sullivan \& Herbert (1965) considered that the serum vitamin $B_{12}$ level would only rise after some degree of tissue repletion had taken place. If this is so then the degree of repletion is extremely variable and obviously minute when compared to the extent of the normal body stores. The very rapid rise in patients $I_{3}$ and $I_{4}$ is of interest. In both it appears that the amount of cyanocobalamin given could only just account for the difference between the value before treatment and that obtained $24 \mathrm{~h}$ after the first injection and sustained during the period of treatment. These results raise the possibility that the injected cyanocobalamin released stored cobalamin into the circulation and that the observed increase was due to cobalamin en route from methylmalonyl coenzyme $\mathrm{A}$ isomerase in liver to bone marrow. The fact that in both patients the cobalamin deficiency followed partial gastrectomy may be relevant.

In conclusion we comment briefly on the general clinical aspects of therapeutic trials. The diagnostic value of these procedures is obvious, particularly when microbiological assay and isotope techniques are not available. In our experience, however, they are laborious and time consuming, fallible in cases in which the deficiency is of dietary origin unless strict dietary control is established and involve a risk to the ill patient which is not entirely negated by blood transfusion which has been found necessary by some workers. Where alternative diagnostic methods are available we consider that therapeutic trials should only be initiated after much thought, including a full appreciation of the responses which may be observed.

We are grateful to Dr L. D. W. Scott, Dr S. Lazarus, Dr G. B. Shaw, Dr A. Allison and the late Dr A. G. Melrose of the Southern General Hospital, and Dr I. A. Short of the Western Infirmary, Glasgow, for referring cases for study. We acknowledge with thanks supplies of cyanocobalamin specially prepared for the investigation by Glaxo Research Ltd.

\section{REFERENCES}

Adams, J. F., Glen, A. I. M., Kennedy, E. H., Mackenzie, I. L., Morrow, J. M., Anderson, J. R., Gray, K. G. \& Middleton, D. G. (1964). Lancet i, 401 .

Boddy, K. \& Adams, J. F. (1968). Am. F. clin. Nutr. 2r, 657.

Cox, E. V., Robertson-Smith, D., Small, M. \& White, A. M. (1968). Clin. Sci. 35, 123.

Cox, E. V. \& White, A. M. (1962). Lancet ii, 853 .

Dacie, J. V. \& Lewis, S. M. (1963). Practical Haematology, $3^{\text {td }}$ ed. London: J. and A. Churchill Ltd.

Darby, W. J., Bridgforth, E. B., Le Brocuy, J., Clark, S. J., De Oliviera, J. D., Kevany, J., McGanity,

W. J. \& Perez, C. (1958). Am. F. Med. 25, 726.

Gompertz, D., Jones, J. H. \& Knowles, J. P. (1967). Lancet i, 424.

Gottlieb, C., Lau, K-S., Wasserman, L. R. \& Herbert, V. (I965). Blood 25, 875.

Hansen, H. A. \& Weinfeld, A. (1 962). Acta med. scand. 172, 472.

Hawkins, C. F. (1955). Br. med. F. i, 383 .

Heyssel, R. M., Bozian, R. C., Darby, W. J. \& Bell, M. C. (I966). Am. F. clin. Nutr. 18, r76.

Hutner, S. H., Bach, M. K. \& Ross, G. I. M. (1956). F. Protozool. 3, Ior.

Kay, A. W. (1953). Br. med. F. ii, 77.

Kohn, J., Mollin, D. L. \& Rosenbach, L. M. (196r). J. clin. Path. I4, 345.

Marshall, R. A. \& Jandl, J. H. (1960). Archs intern. Med. 105, 352.

Ramsay, W. N. M. (1957). Clinica. chim. Acta 2, 214.

Roe, J. H. \& Rice, E. W. (r948). F. biol. Chem. 173, 507.

Schilling, R. F. (1953). F. Lab. clin. Med. 42, 860.

Sullivan, L. W. \& Herbert, V. (1 965). New Engl. J. Med. 272, 340. 
Ungley, C. C. (1949). Br. med. F. ii, 1370.

Varley, H. (1958). Practical Clinical Biochemistry, and ed. London: Heinemann.

Vivacqua, R. J., Myerson, R. M., Prescott, D. J. \& Rabinowitz, J. L. (1966). Am. J. med. Sci. 25 I, 507.

Waters, A. W. \& Mollin, D. K. (1963). Br. F. Haemat. 9, 319.

White, A. M. (1 965). Biochem. F. 95, $17 P$ 